\title{
PENINGKATAN KUALITAS DAN PERSENTASE KARKAS AYAM PEDAGING DENGAN SUBTITUSI BUNGKIL KEDELAI MENGGUNAKAN TEPUNG BIJI ASAM (Tamarindus indica L) FERMENTASI
}

\author{
Improving of Quality and Presentage of Carcass of Broiler Using Tamarinds \\ (Tamarindus indica L) Flour as a Substitute for Soy Bean Meal in Feed
Ika Widiyawati*1), Osfar Sjofjan. $^{2)}$, D.N, Adli $^{3)}$
1) Mahasiswa Program Studi Sarjana Peternakan, Fakultas Peternakan, Universitas Brawijaya Jalan Veteran, Ketawanggede, Kec. Lowokwaru, Kota Malang, Jawa Timur Indonesia 65145
${ }^{2)}$ Dosen Bagian Nutrisi dan Makanan Ternak, Fakultas Peternakan, Universitas Brawijaya Jalan Veteran, Ketawanggede, Kec. Lowokwaru, Kota Malang, Jawa Timur Indonesia 65145
3) Mahasiswa Program Studi Doktor Ilmu Ternak, Fakultas Peternakan, Universitas Brawijaya Jalan Veteran, Ketawanggede, Kec. Lowokwaru, Kota Malang, Jawa Timur Indonesia 65145 \\ Email: ikawidiyawati1205@gmail.com \\ Diterima Pasca Revisi: 27 Februari 2020 \\ Layak Diterbitkan: 1 Maret 2020
}

\begin{abstract}
ABSTRAK
Tujuan penelitian ini adalah untuk mengetahui pengaruh penggunaan tepung biji asam (Tamarindus indica L) fermentasi sebagai subtitusi bungkil kedelai dalam pakan terhadap kualitas karkas ayam pada pedaging. Pengukuran variabel yang digunakan adalah bobot karkas, persentase karkas, bobot daging dada, persentase deposisi daging dada, bobot paha bawah dan persentase paha bawah ayam pada pedaging. Data dianalisis dengan analisis variansi (anova), apabila terdapat perbedaan yang nyata dilanjutkan dengan uji lanjut Duncan's Multiple Range Test (DMRT). Perlakuan dalam penelitian ini adalah PO: Pakan basal tanpa penggantian bungkil kedelai, $P 1$ pakan dengan pengganti bungkil kedelai dengan biji asam fermentasi 25\%, P2: pakan dengan pengganti bungkil kedelai dengan biji asam fermentasi 50\%, P3: pakan dengan pengganti bungkil kedelai dengan biji asam fermentasi 75\%, P4: pakan dengan pengganti bungkil kedelai dengan biji asam fermentasi 100\%. Hasil penelitian menunjukkan penggunaan tepung biji asam fermentasi sebagai pengganti bungkil kedelai memberikan pengaruh tidak nyata $(P>0,05)$ terhadap bobot karkas, persentase karkas, bobot dada, persentase deposisi daging dada, bobot paha bawah dan persentase paha. Kesimpulan dari penelitian ini adalah penggunaan tepung biji asam (Tamarindus indica L) fermentasi dalam pakan dapat dijadikan sebagai subtitusi bungkil kedelai dan memberikan hasil yang sama sampai dengan level penggunaan 50\% terhadap kualitas karkas yaitu bobot karkas, persentase karkas, bobot dada, persentase deposisi daging dada, bobot paha bawah dan persentase paha bawah ayam pedaging.
\end{abstract}

Kata kunci: Ayam pedaging, bungkil kedelai, biji asam, bobot daging dada, fermentasi.

How to Cite:

Widiyawati, I., Sjofjan, O., \& Adli, D.N. (2020). Peningkatan Kualitas dan Persentase Karkas Ayam Pedaging Dengan Subtitusi Bungkil Kedelai Menggunakan Tepung Biji Asam (Tamarindus indica L) Fermentasi. Jurnal Nutrisi Ternak Tropis 3 (1) $35-40$
*Corresponding author:

Ika Widiyawati

Email: ikawidiyawati1205@gmail.com

Fakultas Peternakan, Universitas Brawijaya Jalan Veteran, Ketawanggede, Kec. Lowokwaru, Kota Malang, Jawa Timur Indonesia 65145 


\section{ABSTRACT}

The purpose of this research was to determine the effect of tamarind flour as a substitute for soy bean meal in a feed to the percentage of carcass, internal organs and abdomen fat of broilers. This research used 20 head of Lohmann broiler. The method of this research was experimental laboratory using Completely Randomized Design (CRD) with 5 treatments and 4 replications. The treatment were P0: Basal feed (control), P1: Basal feed substitute soy bean meal with tamarind flour 25\%, P2: Basal feed substitute soy bean meal with tamarind flour 50\%, P3: Basal feed substitute soy bean meal with tamarind flour 75\%, P4: Basal feed substitute soy bean meal with tamarind flour 100\%. The variables observed were the Carcass. Data analysis from this studyAnalysis of Variance (anova) and Duncan's Multiple Range Test (DMRT). The results showed that the used of tamarind flour didn't give a significant effect $(P>0,05)$ on carcass. It can be conclude that tamarind feedstuff can be used as a substitute for soy bean because it has the same effect on broiler.

Keywords: Broiler, carcass, tamarinds.

\section{PENDAHULUAN}

Populasi penduduk Indonesia pada tahun 2019 mencapai 269 juta jiwa dan semakin meningkat tiap tahunnya. Beberapa pakar menyatakan bahwa tingkat konsumsi daging ayam ras perkapita /tahun pada tahun 2017 sebesar 5,68 kg per kapita/tahun, meningkat $573 \mathrm{~g}(11,2 \%)$ dibanding tahun sebelumnya. Ayam pedaging mengalami perkembangan yang pesat dalam pertambahan bobot badan dan relatif singkat untuk umur panennya. Pakan unggas adalah campuran beberapa macam bahan pakan yang diberikan kepada unggas untuk memenuhi kebutuhan, perkembangan dan reproduksi (Muharlien, Achmanu dan Rachmawati, 2011). Mineral, vitamin, dan air (Subekti, 2009). Biaya pakan dalam usaha budidaya ternak unggas (ayam pedaging) merupakan komponen terbesar, yaitu sekitar $70 \%$ dari total biaya produksi. Salah satu bahan sumber protein yang biasa digunakan untuk campuran pakan unggas yaitu bungkil kedelai, namun ketersediaannya masih terbatas sehingga masih mengandalkan dari hasil impor.

Salah satu upaya yang dapat dilakukan untuk mengganti penggunaan bungkil kedelai sebagai sumber protein adalah dengan menggunakan bahan pakan lokal yang mempunyai kandungan nutrisi yang tinggi. Bahan pakan lokal yang dapat digunakan sebagai sumber protein salah satunya adalah biji asam (Tamarindus indica $L$ ) fermentasi. Tamarindus indica $L$ atau asam jawa merupakan tanaman leguminosa yang banyak dijumpai di Indonesia. Selain digunakan sebagai bumbu dapur dan minuman tradisional, biji buah asam memiliki potensi sebagai bahan baku pakan alternatif. Kandungan protein biji asam berkisar antara 22,4-31,3\% dan karbohidrat sebesar 46- $63,3 \%$ serta biji asam memiliki kandungan antinutrisi yang meliputi tannin, asam fitat dan trypsin inhibitor, kandungan lemak pada biji asam Sebesar 1\% (Subagio, 2010). Adanya kandungan antinutrisi pada biji asam tersebut, diperlukan suatu rekayasa teknologi dengan tujuan penghilangan kandungan antinutrisi tersebut sehingga biji asam tersebut dapat digunakan sebagai bahan pakan alternatif sumber protein pengganti bungkil kedelai.

Teknologi fermentasi adalah proses penanaman inokulan yang sesuai ke dalam suatu substrat yang dilanjutkan inkubasi pada suhu dan waktu tertentu dengan tujuan terjadinya proses fermentasi yang dapat meningkatkan nilai nutrisi terutama kadar protein dan menurunkan kadar serat. Tepung biji asam fermentasi dapat digunakan sebagai alternatif bahan pakan sumber protein pengganti bungkil kedelai bagi unggas yang diduga mampu meningkatkan penampilan produksi dan 
kualitas karkas ayam pedaging. Berdasarkan uraian diatas maka perlu adanya penelitian mengenai pengaruh penggunaan tepung biji asam fermentasi sebagai subtitusi bungkil kedelai dalam pakan terhadap bobot karkas, persentase karkas, persentase deposisi daging dada dan bobot daging paha bawah dan juga kualitas karkas dari ayam pedaging setelah diberikan pakan perlakuan tepung biji asam fermentasi.

\section{MATERI DAN METODE}

Metode yang digunakan dalam penelitian ini adalah percobaan in vivo dengan menggunakan Rancangan Acak Lengkap (RAL) yang teridiri dari 5 perlakuan percobaan dan 4 ulangan, 25 ekor ayam pedaging platinum strain Cobb yang tidak dibedakan jenis kelaminnya (unsexed) dengan rataan 49,67 \pm 3,3 dengan koefisien keragaman $7,5 \%$. Pakan yang digunakan adalah sebagai berikut:

$\mathrm{P} 0=$ pakan tanpa pengganti bungkil kedelai

$\mathrm{P} 1=$ pakan dengan pengganti bungkil kedelai dengan biji asam fermentasi $25 \%$

$\mathrm{P} 2=$ pakan dengan pengganti bungkil kedelai dengan biji asam fermentasi $50 \%$

P3= pakan dengan pengganti bungkil kedelai dengan biji asam fermentasi $75 \%$

$\mathrm{P} 4=$ pakan dengan pengganti bungkil kedelai dengan biji asam fermentasi 100.

Parameter yang diamati adalah bobot karkas, persentase karkas, bobot dada, persentase deposisi daging dada, bobot paha bawah dan persentase paha bawah ayam pedaging. Data yang diperoleh dianalisis menggunakan analisis ragam dari Rancangan Acak Lengkap (RAL) menggunakan aplikasi SAS version 9.4. Apabila hasil penelitian menunjukkan pengaruh nyatta $(\mathrm{P}<0,05)$ atau sangat nyata $(\mathrm{P}<0,01)$ maka dilanjutkan dnegan Uji Jarak Berganda Duncan's (UJBD). Metode dalam RAL yang digunakan adalah sebagai berikut:

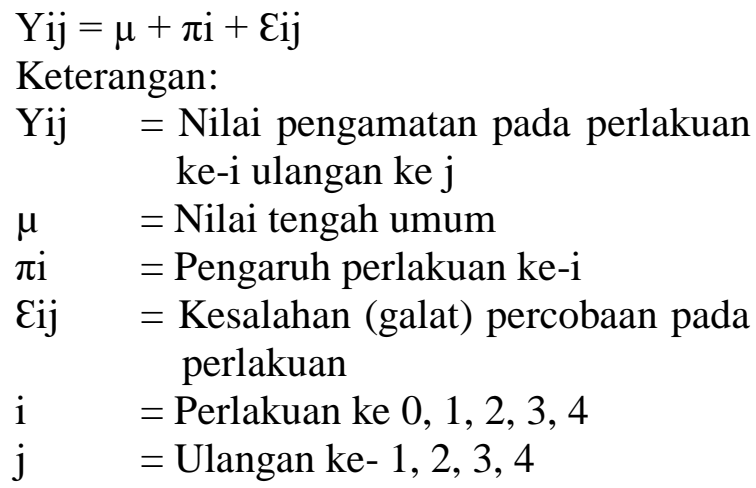

\section{HASIL DAN PEMBAHASAN}

\section{Pengaruh Perlakuan Terhadap Bobot Karkas}

Bobot karkas merupakan gambaran dari produksi daging dari seekor ternak dan pengukuran bobot karkas merupakan suatu faktor yang penting dalam mengevaluasi hasil produksi ternak. Menurut Putra, Rukmiasih dan Afnan, (2015), bobot karkas tidak dipengaruhi oleh jenis kelamin dari ternak. Berdasarkan hasil penelitian yang telah dilakukan, didapatkan rata-rata bobot karkas ayam pedaging pada Tabel 1 . menunjukkan P0 (1066 \pm 39,45); P1 (1056 $\pm 28,61) ; \mathrm{P} 2(1048,5 \pm 26,66) ; \mathrm{P} 3$ (1041,75 \pm 34,71); P4 (1054 \pm 16,10) dalam satuan g/ekor.

Bobot karkas dari hasil penelitian ini masih lebih tinggi dibandingkan dengan penelitian yang dilakukan oleh Nelwida (2011) yaitu sebesar 650 - 850 g/ekor. Perlakuan tepung biji asam fermentasi terhadap bobot karkas memberikan pengaruh tidak nyata $(\mathrm{P}>0,05)$. Produksi karkas erat hubungannya dengan bobot hidup yaitu peningkatan bobot hidup diikuti oleh peningkatan bobot karkas (Londok, John, Rompis, dan Mangelep, 2017). Semakin tinggi bobot hidup, maka semakin tinggi pula bobot karkas yang diperoleh. Analisis statistik memberikan pengaruh tidak nyata, berdasarkan hasil rata-rata bobot karkas yang tersaji pada Tabel 1 .

Perlakuan P1 (1056 \pm 28,61 g/ekor) menunjukkan hasil perlakuan terbaik dibandingkan dengan perlakuan yang lainnya. Hal ini disebabkan oleh bobot hidup perlakuan P1 yang lebih tinggi pula 
dibandingkan dengan perlakuan yang lain dengan pemberian tepung biji asam fermentasi 25\%. Semakin tinggi bobot hidup maka berpengaruh terhadap produksi karkas yang semakin meningkat.

\section{Pengaruh Perlakuan Terhadap Persentase Karkas}

Persentase karkas diperoleh dengan cara membandingkan bobot karkas dengan bobot hidup ayam pedaging kemudian dikalikan dengan 100\%. Hal tersebut didukung oleh Massolo, Mujnisa, dan Agustina (2016) yang menyatakan bahwa karkas ayam pedaging diperoleh dari bagian tubuh ayam yang disembelih dan telah dikurangi kepala, leher, kaki, bulu, darah, dan isi perutnya. Berdasarkan hasil penelitian yang telah dilakukan, didapatkan rata-rata persentase karkas ayam pedaging Tabel 1.

Tabel 1. Rata-rata pengaruh perlakuan terhadap bobot karkas, bobot daging dada, bobot paha bawah, persentase karkas, persentase deposisi daging dada dan persentase paha bawah ayam pedaging.

\begin{tabular}{lccccc}
\hline Variabel & P0 & P1 & P2 & P3 & P4 \\
\hline Bobot Karkas (gram) & $1066 \pm 39,45$ & $1056 \pm 28,61$ & $1048,5 \pm 26,66$ & $1041,75 \pm 34,71$ & $1054 \pm 16,10$ \\
Bobot Daging Dada (gram) & $256,5 \pm 2,08$ & $254 \pm 5,66$ & $254 \pm 6,32$ & $254,8 \pm 6,18$ & $256,3 \pm 4,86$ \\
Bobot paha bawah (gram) & $135,3 \pm 1,5$ & $122 \pm 18,83$ & $125,5 \pm 14,98$ & $126,5 \pm 11,70$ & $124,5 \pm 18,72$ \\
Persentase Karkas (\%) & $61,16 \pm 2,32$ & $61,08 \pm 2,57$ & $60,14 \pm 0,67$ & $60,89 \pm 0,71$ & $59,76 \pm 0,54$ \\
Persentase Deposisi Daging & $11,26 \pm 0,43$ & $11,64 \pm 0,95$ & $11,07 \pm 0,64$ & $11,02 \pm 0,49$ & $11,31 \pm 0,62$ \\
Dada (\%) & & & & \\
Persentase Paha Bawah (\%) & $8,34 \pm 0,47$ & $7,62 \pm 1,19$ & $8,25 \pm 1,26$ & $8,05 \pm 0,45$ & $7,87 \pm 0,60$ \\
\hline
\end{tabular}

Pada umur 35 hari menunjukkan persentase berturut- turut yaitu P0 $(61,16 \pm$ $2,32 \%) ; \mathrm{P} 1(61,08 \pm 2,57 \%) ; \mathrm{P} 2(60,14 \pm$ $0,67 \%) ; \mathrm{P} 3(60,89 \pm 0,71 \%) ; \mathrm{P} 4(59,76 \pm$ $0,54 \%)$. Penggunaan tepung biji asam fermentasi dalam pakan memberikan pengaruh tidak nyata $(\mathrm{P}>0,05)$ terhadap persentase karkas ayam pedaging. Hasil penelitian dari Massolo, Mujnisa, dan Agustina (2016) presentase karkas rata-rata yang dihasilkan tidak jauh berbeda yaitu $66,37 \pm 2,96 \%$.

\section{Pengaruh Perlakuan Terhadap Persentase Deposisi Daging Dada}

Dada merupakan salah satu bagian potongan karkas yang diminati oleh masyarakat karena memiliki perdagingan yang tebal. Menurut Putra, Rukmiasih dan Afnan, (2015), potongan bagian dada unggas memiliki perdagingan yang tebal dengan tulang yang kecil. Deposisi daging dada adalah bagian daging dada ayam yang diambil tanpa tulang kemudian dilakukan penimbangan. Faktor kandungan nutrisi dalam pakan terutama protein akan berpengaruh terhadap bobot karkas yang berbeda dan membuat persentase deposisi daging dada berbeda pula. Rata-rata persentase deposisi daging dada ayam pedaging yang diberi pakan perlakuan tepung biji asam fermentasi disajikan pada Tabel 1.

Hasil penelitian menunjukkan bahwa penggunaan tepung biji asam fermentasi dalam pakan sebagai subtitusi bungkil kedelai diperoleh presentase deposisi daging dada yaitu P0 (11,26 \pm 0,43\%); P1 (11,64 \pm $0,95 \%) ; \mathrm{P} 2(11,07 \pm 0,64 \%) ; \mathrm{P} 3(11,02 \pm$ $0,49 \%)$; P4 $(11,31 \pm 0,62 \%)$ penggunaan tepung biji asam fermentasi dalam pakan memberikan pengaruh tidak nyata $(\mathrm{P}>0,05)$ terhadap persentase deposisi daging dada ayam pedaging. Hasil penelitian ini masih lebih rendah dibandingkan dengan hasil penelitian Anggitasari, Sofjan dan Djunaidi (2016) nilai deposisi daging dada paling tinggi terdapat pada pakan perlakuan P2 sebesar 28,6\%. Hal ini dipengaruhi oleh faktor kandungan nutrisi dalam pakan khususnya protein, sehingga menghasilkan bobot karkas yang berbeda dan membuat persentase deposisi daging dada menjadi berbeda pula.

\section{Pengaruh Perlakuan Terhadap Bobot Daging Dada}

Nilai rata-rata dari penggunaan tepung biji asam fermentasi sebagai subtitusi bungkil kedelai dalam pakan terhadap bobot 
daging dada dapat dilihat pada Tabel 1 . Rata-rata hasil perlakuan secara berturutturut yaitu P0 $(256,5 \pm 2,08)$; P1 (254 \pm 5,66); P2 (254 $\pm 6,32) ; \mathrm{P} 3(254,8 \pm 6,18) ; \mathrm{P} 4$ $(256,3 \pm 4,86)$ dalam satuan g/ekor, yang menunjukkan bahwa penggunaan tepung biji asam fermentasi memberikan pengaruh tidak nyata $(\mathrm{P}>0,05)$. Pengaruh memberikan hasil yang berpengaruh nyata, berdasarkan hasil rata-rata bobot daging dada ayam pedaging yang tersaji pada Tabel 1 . Perlakuan P4 yaitu 256,3 \pm 4,86 g/ekor menunjukkan hasil perlakuan terbaik dibandingkan dengan perlakuan yang lainnya dengan pemberian perlakuan tepung biji asam fermentasi $100 \%$.

Perlakuan P1 menunjukkan hasil paling rendah yaitu sebesar $254 \pm 5,66$ g/ekor dengan pemberian tepung biji asam fermentasi sebanyak 25\%. Hal ini dikarenakan persentase bobot dada ayam bertambah sejalan dengan bertambahnya bobot ayam. Kecenderungan peningkatan berat potongan komersial karkas bagian dada, karena potongan komersial karkas bagian dada merupakan bagian karkas yang banyak mengandung otot jaringan yang perkembangannya lebih dipengaruhi oleh zat makanan khususnya protein (Ariawan., Siti dan Sukmawati, 2016).

\section{Pengaruh Perlakuan Terhadap Persentase Paha Bawah}

Bagian paha merupakan salah satu bagian dari tubuh ayam yang mengandung daging yang tebal Pengaruh perlakuan terhadap persentase paha bawah dapat dilihat pada Tabel 1.

Rata-rata hasil perlakuan secara berturut-turut yaitu P0 $(8,34 \pm 0,47 \%)$; P1 $(7,62 \pm 1,19 \%) ; \mathrm{P} 2(8,25 \pm 1,26 \%) ; \mathrm{P} 3(8,05$ $\pm 0,45 \%) ; \quad \mathrm{P} 4 \quad(7,87 \pm 0,60 \%)$ yang menunjukkan bahwa penggunaan tepung biji asam fermentasi memberikan pengaruh tidak nyata $(\mathrm{P}>0,05)$. Dari data tersebut didapatkan bahwa penggunaan tepung biji asam fermentasi memberikan pengaruh tidak nyata terhadap persentase paha bawah ayam pedaging. Hasil penelitian ini lebih rendah jika dibandingkan dengan hasil penelitian dari Ramdani, Kardaya dan
Anggraeni (2016) dengan rata-rata persentase paha bawah pada setiap perlakuan antara 16,41 - 17,28\% dan Astuti (2014) yaitu $13,28-14,11 \%$. Persentase daging bagian paha bawah merupakan anggota gerak sehingga komponen daging sedikit dan kurang mendapatkan respon dibandingkan komponen daging bagian paha atas (Imamudin, Atmomarsono, \& Nasoetion, 2012).

\section{KESIMPULAN}

Penggunaan tepung biji asam (Tamarindus indica L) fermentasi dalam pakan dapat dijadikan sebagai subtitusi bungkil kedelai dan memberikan hasil yang sama sampai dengan level penggunaan 50\% terhadap kualitas karkas yaitu bobot karkas, persentase karkas, bobot dada, persentase deposisi daging dada, bobot paha bawah dan persentase paha bawah ayam pedaging.

\section{DAFTAR PUSTAKA}

Imamudin, U., Atmomarsono, M. H., \& Nasoetion. (2012). Pengaruh berbagai frekuensi pemberian pkan pada pembatasan pakan terhadap produksi karkas ayam broiler. Animal Agricultural Journal, 1(1), 87-89.

Massolo, R., Mujnisa, A., \& Agustina, L. (2016). Persentase karkas dan lemak abdominal broiler yang diberi prebiotik inulin umbi bunga dahlia (Dahlia variabillis). Buletin Nutrisi Dan Makanan Ternak, 12(2), 50-58.

Muharlien, Achmanu, \& Rachmawati, R. (2011). Meningkatkan produksi ayam pedaging melalui pengaturan proporsi sekam, pasir dan kapur sebagai litter. TERNAK TROPIKA Journal of Tropical Animal Production, 12(1), 38-45.

Ramdani, I., Kardaya, D., \& Anggraeni, A. (2016). Pengaruh subtitusi pakan komersil dengan tepung ampas kelapa 
terhadap bobot potong dan bobot karkas ayam kampung. Jurnal Peternakan Nusantara, 2(1), 9-16. https://doi.org/10.30997/jpnu.v2i1.323

Sitompul, S. A., Sjofjan, O., \& Djunaidi, I. H. (2016). Pengaruh beberapa jenis pakan komersial terhadap kinerja produksi kuantitatif dan kualitatif ayam pedaging. Buletin Peternakan, 40(3), 187-196. https://doi.org/10.21 059/buletinpeternak.v40i3.11622
Subagio, A. (2006). Characterization of hyacinth bean (Lablab purpureus (L.) sweet) seeds from Indonesia and their protein isolate. Food Chemistry, 95(1), 65-70. https://doi.org/10.1016 /j.foodchem.2004.12.042

Subekti, E. (2010). Ketahanan pakan ternak indonesia. Jurnal Ilmu-Ilmu Pertanian, 5(2), 63-71.

Widodo, W. (2011). Nutrisi dan Pakan Unggas Kontekstual. 